\title{
Hydraulic fracturing design improvements by proppant flowback mitigation method application during hydrocarbon production
}

Rudarsko-geološko-naftni zbornik

(The Mining-Geology-Petroleum Engineering Bulletin) UDC: 622.276

DOI: 10.17794/rgn.2021.1.8

Review scientific paper

\author{
Temirlan Jatykov'; Bimurat Sagindykov ${ }^{2}$; Kuralay Bimuratkyzy ${ }^{3}$ \\ ${ }^{1}$ Kazakh-British Technical University, Almaty, 050000, Tole bi Str. 59, Kazakhstan, ORCID 0000-0002-2309-464X \\ ${ }^{2}$ Satpayev University, Almaty, 050013, Satpayev Str., 22, Kazakhstan, ORCID 0000-0002-5349-1961 \\ ${ }^{3}$ Expert Team LLP, Almaty, 050046, Yegizbayev Str. 7/5, Kazakhstan, ORCID 0000-0002-8541-8945
}

\begin{abstract}
Proppant flowback after hydraulic fracturing treatment is quite a serious challenge that causes damage to both downhole and surface equipment, leading to unwanted workovers and production suspension, or other negative outcomes. Some special methods including preventive as well as corrective measures already exist in the industry to overcome the proppant flowback problems. However, there is no clear guidance on how to choose the method for certain conditions, particularly during the hydraulic fracturing design stages. Therefore, the authors conducted a comprehensive review of fourteen preventive technologies to systematize them and to propose an initial decision-making approach. The following methods were considered in this paper: Resin Coated Proppants (RCP), RCP with Activator, RCP with Nanoparticles, Proppant with Liquid Resin Systems (LRS), Proppant with Surface Modification Agents (SMA), Proppant with Proppant Consolidation Aid (PCA), Cylindrical Proppant, Microfibers, Thermoset Resin Fibers, Thermoset Film Strips, Deformable Isometric Particles (DIP), Expandable Proppants, Polymer Surface Modified Proppants, and In-situ Formulated Proppants. The review reveals physical, chemical, and technological properties of each method to select criteria for effective screening. So, the reader could find the appropriate proppant flowback mitigation method corresponding to a particular reservoir and the well conditions during the initial hydraulic fracturing design stages.
\end{abstract}

Keywords:

hydraulic fracturing; proppant flowback; resin coated proppant; unconventional reservoirs; mature fields.

\section{Introduction}

Hydraulic fracturing treatments are widely considered to be a good way to produce hydrocarbons from a majority of fields. This is especially valid for low and ultra-low permeability reservoirs, tight oil, shale gas, mature fields and other unconventional reservoirs (Bomgardner 2011; Istayev et al., 2019). The main material used in the process of fracturing is a proppant to keep a fracture open after pressure is released. Conventionally, sands, ceramics, resin coated sands or ceramics, as well as bauxites are used as proppants.

A challenging problem which arises in hydraulic fracturing domain is proppant flowback during a well's life after the treatment. Proppant flowback results in many field problems, all leading to well production decline, and some of them are listed below (Nguyen et al., 2003; 2013):

- damage to the surface and downhole equipment (pumps, screens, etc.),

- premature fracture closure near the wellbore,

- bottomhole and partial or full perforation blockage due to proppant settling,

Corresponding author: Temirlan Jatykov

t.dzhatykov@kbtu.kz
- frequent workovers,

- back produced proppant utilization (transportation, cleaning).

Actually, many methods exist to mitigate the proppant flowback problems. They can be subdivided into preventive and post factum. Methods based on the drawdown regulation, fracture closure time regulation, injecting various bonding compositions into an existing fracture and so forth are considered as post factum, because they are implemented after hydraulic fracturing in the event that the problems occur. However, post factum methods can sometimes be used together with the preventive methods in case the latter couldn't cope with the problem itself.

On the other hand, the preventive methods are subdivided based on the pumping schedule, used materials, applied equipment and are designed in the beginning of fracturing operations. This paper considers fourteen preventive methods: Resin coated proppant (RCP), RCP with activator, RCP with nanoparticles, Proppant with a Liquid Resin System (LRS), Proppant with a Surface Modification Agent (SMA), Proppant with a Proppant Consolidation Aid (PCA), Cylindrical Proppant, Microfibers, Thermoset Resin Fibers (TRF), Thermoset Film Strips (TFS), Deformable Isometric Particles (DIP), Ex- 
Table 1: Common reasons for proppant flowback problem

\begin{tabular}{|c|c|c|}
\hline \# & Proppant flowback reasons & Description \\
\hline 1 & $\begin{array}{l}\text { Unstable bottomhole } \\
\text { conditions }\end{array}$ & $\begin{array}{l}\text { For instance, proppant pack is under high drawdowns (Abbott et al., 2008; Valiullin et al., } \\
\text { 2015; Vreeburg et al., 1994). }\end{array}$ \\
\hline 2 & Proppant washouts & $\begin{array}{l}\text { Slow or fast proppant particles washouts from small cement sheaf voids, sumps, cavities } \\
\text { near wellbore (Nguyen et al., 2003; Van Batenburg et al., 1999). }\end{array}$ \\
\hline 3 & $\begin{array}{l}\text { Partial proppant grain } \\
\text { deformation and crash }\end{array}$ & $\begin{array}{l}\text { Caused by higher loads during the reservoir pressure decline, and subsequently } \\
\text { the overburden pressure increases (Nguyen et al., 2003; Valiullin et al., 2015). }\end{array}$ \\
\hline 4 & A slow fracture closure & $\begin{array}{l}\text { Resulting from slow gel breakage in the end of pumping, it can tend to the proppant } \\
\text { settling to the bottom of the fracture with consequent rearrangements of proppant bonding } \\
\text { agents (RCP, resin compositions). This diminishes the effect of the bonding agents } \\
\text { (Gubanov et al., 2009; Nguyen et al., 2003). }\end{array}$ \\
\hline 5 & $\begin{array}{l}\text { Negative impact of some gel } \\
\text { properties on the RCP } \\
\text { bonding }\end{array}$ & $\begin{array}{l}\text { This is supported by Abbott et al., 2008; Gubanov et al., 2009; Nguyen et al., 2003; } \\
\text { Vreeburg et al., 1994. For example, high pH (e.g. more than 12), persulphate based } \\
\text { breakers, and titan crosslinkers are those leading to the degradation of RCP proppants. } \\
\text { Gel crosslinkers could be left on the surface of RCP or on other bonding agents, which } \\
\text { diminishes their effectiveness. }\end{array}$ \\
\hline 6 & Increase in gas to liquid ratio & $\begin{array}{l}\text { Kurochkin et al., } 2015 \text { claim that this leads to an increase in proppant flowback rate. } \\
\text { This could happen when bottomhole pressure is below the bubble point. The physics } \\
\text { behind this is a multiphase flow which increases hydrodynamic friction in the fracture. }\end{array}$ \\
\hline 7 & Well deviation & $\begin{array}{l}\text { Highly deviated wells tend to increase proppant production more than vertical ones } \\
\text { (Browne and Wilson, 2003). }\end{array}$ \\
\hline 8 & $\begin{array}{l}\text { Produced fluid's high } \\
\text { viscosity }\end{array}$ & $\begin{array}{l}\text { Aggressive pumping schedule during Tip Screen Out (TSO), and cyclic stresses } \\
\text { are the factors contributing to proppant flowback as per (Letichevskiy et al., 2015). }\end{array}$ \\
\hline 9 & Back production & $\begin{array}{l}\text { Up to } 20 \% \text { of total proppant initially pumped can be returned after a treatment } \\
\text { (Cudney et al., 1997) }\end{array}$ \\
\hline 10 & Weak formations & $\begin{array}{l}\text { Shallow reservoirs with small stresses hold proppant pack poorly. Uneven proppant } \\
\text { distribution along the fracture with empty lags, gaps, islands of proppant are other reasons } \\
\text { for flowback (Lu et al., 2016). }\end{array}$ \\
\hline 11 & $\begin{array}{l}\text { Weakening of the curing } \\
\text { process }\end{array}$ & $\begin{array}{l}\text { As per (Nguyen et al., 2003) in low permeability reservoirs, the fractures don't close } \\
\text { in } 24 \text { hours, and sometimes even up to } 90 \text { days later. In such situations, when the well } \\
\text { is put into production, RCP cannot completely cure and starts to be produced back with } \\
\text { reservoir fluids. Another observation is high shear stresses applied to proppant grains and } \\
\text { coating (during pumping starting from surface and ending in the fracture). The latter is } \\
\text { also supported by Vincent et al., } 2004 \text {. }\end{array}$ \\
\hline 12 & Gel viscosity & $\begin{array}{l}\text { Norman et al., } 1992 \text { mentioned that the increase in gel viscosity leads to a weakening } \\
\text { of RCP curing. }\end{array}$ \\
\hline 13 & Proppant size & $\begin{array}{l}\text { The bigger the size of proppant grains, the more stable the proppant pack } \\
\text { (Parker et al., 1999). }\end{array}$ \\
\hline 14 & $\begin{array}{l}\text { Missing proppant at the top } \\
\text { of the fracture }\end{array}$ & $\begin{array}{l}\text { Due to a poorly designed fracturing process with overestimated pad size and low quality } \\
\text { gel (Van Batenburg et al., 1999). This tends to create channeling at the fracture top at high } \\
\text { flow rates with subsequent proppant flowback. Almond et al., } 1995 \text { also supports this } \\
\text { idea. }\end{array}$ \\
\hline
\end{tabular}

pandable Proppants, Polymer surface modified proppant, and In-situ Formulated proppant.

The mentioned methods are thoroughly described in literature. However, as far as is known, there is no research in terms of a methods' classification and appropriateness for a particular reservoir or field conditions. It is for this reason that one of the aims of this research is to conduct a deep systematization of data and information founded based on a comprehensive material review.

First of all, a special list of criteria was set based on the physical, chemical, technological, and other properties and parameters, which specify a relationship between the methods and geological and technological objects. Geological objects are those related to reservoir rocks and fluids with related properties. Technological objects are those related to well parameters and various well intervention operations.

Furthermore, the main reasons for proppant flowback support the decision matrix and the algorithm. That is, understating of the main reasons is one of the keys to making a decision on the application of a particular mitigation method. Based on the review of a variety of research and field trials, the list in Table 1 could be considered as the common reasons for proppant flowback.

Our systematized approach can introduce an algorithm and a matrix which could quickly and effectively 
Table 2: Common features for all proppant flowback mitigation methods

\begin{tabular}{|c|c|c|}
\hline \# & Feature & Description \\
\hline 1 & $\begin{array}{l}\text { Flowing a well after } \\
\text { a treatment }\end{array}$ & Despite any applied method, a well starting time decreases after a treatment. \\
\hline 2 & Field applicability & $\begin{array}{l}\text { Most of the methods were successfully tested, both in the laboratory and field trials. More } \\
\text { importantly, actual field scale treatments were performed (except methods } 6,12,13,14 \text {, } \\
\text { as listed in Table 3). }\end{array}$ \\
\hline 3 & $\begin{array}{l}\text { Withstanding for well } \\
\text { flowing rates }\end{array}$ & $\begin{array}{l}\text { The methods can withstand conditions of small and moderate rates, and with special } \\
\text { constraints, high rates as well. }\end{array}$ \\
\hline 4 & $\begin{array}{l}\text { Compatibility with produced } \\
\text { fluids }\end{array}$ & The methods can be used in majority produced fluids. \\
\hline 5 & Flexibility & The methods can be implemented in different well conditions and reservoir properties. \\
\hline 6 & $\begin{array}{l}\text { Applicability in } \\
\text { homogeneous formations }\end{array}$ & The techniques can be equally applied in homogeneous formations. \\
\hline 7 & Fines migrations mitigation & $\begin{array}{l}\text { Whatever method is used, it reduces fines migration and movement, created during partial } \\
\text { grain crashing. }\end{array}$ \\
\hline 8 & Filtration properties & Filtration properties of the fracture increases. \\
\hline 9 & Durability & If the method is appropriately chosen as per the criteria, it could have a long term effect. \\
\hline 10 & Compatibility with chemicals & $\begin{array}{l}\text { Acid and high temperatures are two important factors to be taken into account because the } \\
\text { composition of the majority of the material is resin, which can be affected and } \\
\text { deteriorated by them. }\end{array}$ \\
\hline 11 & Economic considerations & $\begin{array}{l}\text { Although it was stressed in the assumption list that the economic factor was purposely left } \\
\text { out of the matrix, in case of applicability of several appropriate options by the matrix, the } \\
\text { final decision should be made by a user based on information available at the time, e.g. } \\
\text { economics and other local conditions. Under other local conditions, the user could } \\
\text { consider the availability in the area, logistics, policies, laws, etc. This is left for the user's } \\
\text { own decision as a recommendation. }\end{array}$ \\
\hline
\end{tabular}

help to make an initial decision on what method to apply for certain well/field conditions in case of proppant flowback problem potential.

\section{The Decision Matrix for Choosing an Appropriate Mitigation Method}

Based on the review of physical, chemical, and technological properties of currently available materials for application in hydraulic fracturing treatments, fourteen of the most up-to-date flowback mitigation approaches were selected. Preventive methods are listed in Table 3. These methods are characterized by the material filling the fracture. Besides these, one could apply other techniques such as flowing a well with limited drawdown, forced fracture closure, and so forth to support preventive methods. It is understandable that there are methods which can be applied in already fractured wells, for example, pumping special bonding compositions (e.g. formaldehyde resin). However, this paper discusses and considers only those methods which are included in the fracturing design stages for hydrocarbon fields that have potential proppant flowback problems in their production history.

After selecting the list of potential methods, special criteria are set to reveal their practical applicability in conjunction with certain reservoir and well conditions. It is suggested to subdivide the criteria into several categories: reservoir properties, well parameters, material availability, and well intervention operations. Now each of these categories can be refined further into subcategories. Firstly, heterogeneity, fluid phases and viscosities, temperature, permeability, drawdown, and rock stresses are considered as reservoir properties. Secondly, well parameters include well configuration (vertical, deviated or horizontal) and perforation coverage. Thirdly, the material availability is subdivided as a field scale and a lab scale depending on the history of its application in the industry. Fourthly, future planned well intervention operations should also be taken into account, especially workover operations with any acid and thermal treatments.

Understanding that the subject is too complex to be covered in one matrix, the following assumptions are set:

- All methods are in production wells; this is a reasonable assumption because e.g. in injection wells, one of the methods is water injection by thermal proppant fracturing, which means the temperatures of the injection fluids and the reservoir are very important. Thus, production wells are only considered.

- Typical perforations are applied without screens; the assumption is based on the fact that normally screens are themselves the method to cope with particle flowback, thus there is no need for such consideration.

- All acid jobs assume only $\mathrm{HCl}$ or organic acids treatments, or solvent washes but without any HF 


\begin{tabular}{|c|c|c|c|c|c|c|c|c|c|c|c|c|c|c|c|c|}
\hline 竞: & 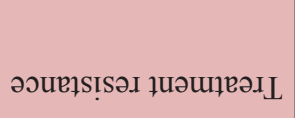 & щвәІS & $\circ$ & & 0 & 0 & & 0 & - & & - & 0 & 0 & 0 & 0 & 0 \\
\hline Iิ & & 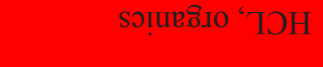 & 0 & 0 & 0 & 0 & 0 & 0 & - & & - & 0 & 0 & 0 & 0 & 0 \\
\hline \multirow{2}{*}{ 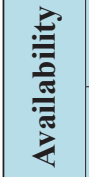 } & әреоs Клоџ.ıоче Т & pałsә $\mathrm{L}$ & - & - & - & - & - & - & - & - & - & - & - & - & - & - \\
\hline & 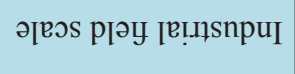 & pə!̣dd $V$ & - & - & - & - & - & 0 & - & - & - & - & - & 0 & 0 & 0 \\
\hline \multirow{4}{*}{ 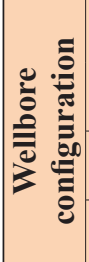 } & \multirow{2}{*}{ 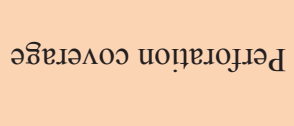 } & 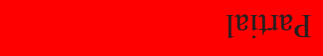 & - & - & - & - & - & - & - & - & - & - & - & - & - & - \\
\hline & & {$\left[\mathrm{I}_{\underline{H}}\right.$} & - & - & - & - & - & - & - & - & - & - & - & - & - & - \\
\hline & [в]UOZ!̣OH & 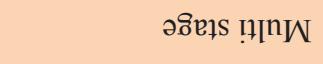 & - & - & - & - & - & - & - & - & - & - & - & - & - & - \\
\hline & [вопп, & 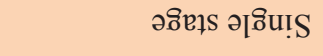 & - & - & - & - & - & - & - & - & - & - & - & - & - & - \\
\hline \multirow{18}{*}{ 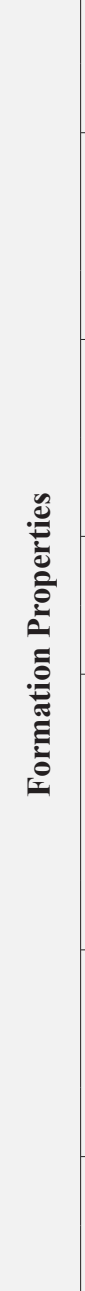 } & \multirow{2}{*}{ 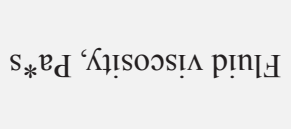 } & К!! & - & - & - & - & - & - & - & - & - & - & - & - & - & - \\
\hline & & 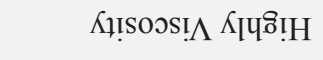 & 0 & 0 & - & - & 0 & - & - & 0 & 0 & 0 & - & - & - & - \\
\hline & \multirow{3}{*}{$\mathrm{e}_{\mathrm{d}}$ 'ssə.nS } & MOI & - & - & - & - & - & - & - & - & - & - & - & - & - & - \\
\hline & & әұย!рәшцәңய & - & - & - & - & - & - & - & - & - & - & - & - & - & - \\
\hline & & ૫จิ! & - & - & - & - & 0 & - & - & - & - & - & - & - & - & - \\
\hline & \multirow{2}{*}{ 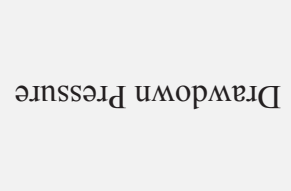 } & 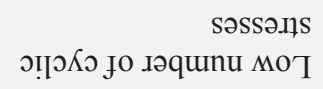 & - & - & - & - & - & - & - & - & - & - & - & - & - & - \\
\hline & & 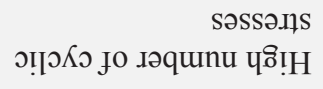 & 0 & 0 & - & - & 0 & - & - & - & - & - & - & - & - & - \\
\hline & \multirow{2}{*}{ حшu ' ‘ } & MOT & - & - & - & - & - & - & - & - & - & - & - & - & - & - \\
\hline & & ૫จิ! !H & - & - & - & - & - & - & - & - & - & - & - & - & - & - \\
\hline & \multirow{4}{*}{ 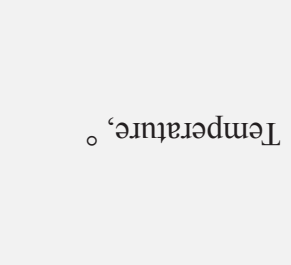 } & $00 z-0 z \mathrm{I}$ & - & 0 & - & - & 0 & 0 & - & 0 & - & - & 0 & - & - & - \\
\hline & & $0 Z I-0 S$ & - & 0 & - & - & - & - & - & - & - & - & - & - & - & - \\
\hline & & $0 \varsigma-0 \varepsilon$ & 0 & 0 & 0 & - & - & - & - & - & - & - & - & - & - & - \\
\hline & & $0 \mathcal{E}^{-0} 0$ & 0 & - & 0 & - & - & - & - & - & - & - & - & - & - & - \\
\hline & \multirow{3}{*}{ 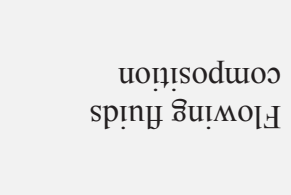 } & SED & - & - & - & - & - & - & - & - & - & - & - & - & - & - \\
\hline & & .ə‡Е $M+$ SED & - & - & - & - & - & - & - & - & - & - & - & - & - & - \\
\hline & & 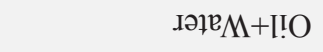 & - & - & - & - & - & - & - & - & - & - & - & - & - & - \\
\hline & \multirow{2}{*}{ snоəนวઠิо.әџәН } & рә.əКв!!ฺnи u!ЧL & - & - & - & - & - & - & - & - & - & - & - & - & - & - \\
\hline & & 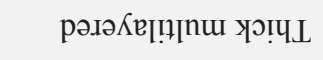 & 0 & 0 & 0 & - & - & - & - & - & - & - & - & - & - & - \\
\hline \multicolumn{3}{|c|}{ 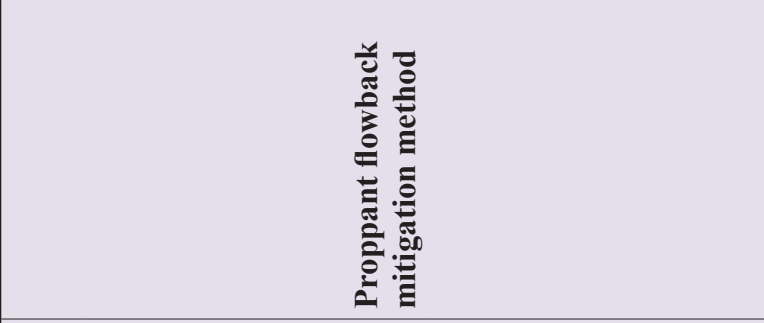 } & $\vec{z}$ & 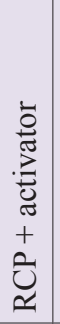 & 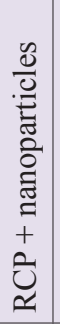 & 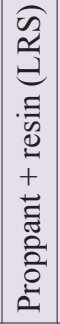 & 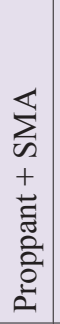 & 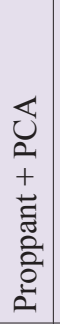 & 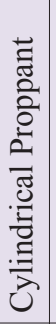 & 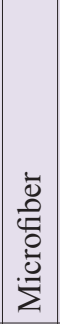 & 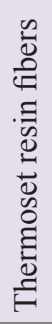 & 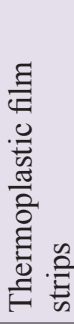 & 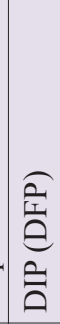 & 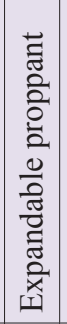 & 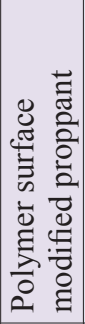 & 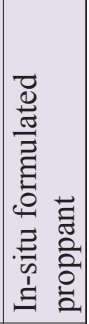 \\
\hline \multicolumn{3}{|c|}{ \# } & - & $N$ & $m$ & + & in & 6 & $r$ & $\infty$ & $a$ & $\varrho$ & $=$ & $\simeq$ & 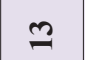 & $\Xi$ \\
\hline
\end{tabular}


Table 4: The classification descriptive table to support the decision matrix based on comprehensive review

\begin{tabular}{|c|c|c|c|}
\hline \# & Method & Description & References \\
\hline 1 & $\begin{array}{l}\text { Resin } \\
\text { coated } \\
\text { proppant } \\
(\mathrm{RCP})\end{array}$ & $\begin{array}{l}\text { The comprehensive review of the studies related to RCP as well as the } \\
\text { knowledge about the reasons for proppant flowback revealed a set of criteria } \\
\text { related to reservoir properties and some typical values (categorical and } \\
\text { numerical). These criteria take into account the conditions of RCP } \\
\text { applicability. Summarized parameters when this method is applied are given } \\
\text { in Table 3, row 1. }\end{array}$ & $\begin{array}{l}\text { Abbott et al., 2008; } \\
\text { Denney, 2005; } \\
\text { Duenckel et al., 2017; } \\
\text { Dewprashad et al., 1993; } \\
\text { Ghosh et al., 2014; } \\
\text { Gorshkov et al., 2018; } \\
\text { Green et al., 2018; } \\
\text { James et al., 1998; } \\
\text { Kushnarenko et al., 2016; } \\
\text { Letichevskiy et al., 2015; } \\
\text { Nguyen et al., 2003; } \\
\text { Shagaleev et al., 2014; } \\
\text { Sidorov and Sabitov, } \\
\text { 2010; Van Batenburg et } \\
\text { al., 1999; Vreeburg et al., } \\
\text { 1994; Wei et al., 2020; } \\
\text { Zoveidavianpoor and } \\
\text { Gharibi, 2015. }\end{array}$ \\
\hline 2 & $\begin{array}{l}\text { RCP with } \\
\text { Curing } \\
\text { Activator }\end{array}$ & $\begin{array}{l}\text { At low temperatures, normally below } 50^{\circ} \text {, when casual RCP is not } \\
\text { applicable, one can add an activator. The activator is normally a fluid to } \\
\text { accelerate the curing process under low temperatures. The rest is the same as } \\
\text { for casual RCP. Summarized parameters when this method is applied are } \\
\text { given in Table 3, row } 2 \text {. }\end{array}$ & $\begin{array}{l}\text { Browne and Wilson, 2003; } \\
\text { Kurochkin et al., 2015; } \\
\text { Kushnarenko et al., 2016; } \\
\text { Shagaleev et al., 2014; } \\
\text { Sidorov and Sabitov, 2010. }\end{array}$ \\
\hline 3 & $\begin{array}{l}\text { RCP } \\
\text { with nano- } \\
\text { particles }\end{array}$ & $\begin{array}{l}\text { Haque et al., } 2019 \text { developed a new method with nanocomposite resin } \\
\text { application, which enhances the quality of a grain's coating resulting } \\
\text { in higher strength and chemical stability. According to comprehensive } \\
\text { laboratory studies, a new technology called Multi-Walled Carbon Nanotubes } \\
\text { (MWNT) exceeds the RCPs and casual frac sand properties, such as strength, } \\
\text { conductivity, and chemical stability. Summarized parameters and ranges } \\
\text { of applicability of the method are given in Table 3, row } 3 \text {. }\end{array}$ & Haque et al., 2019. \\
\hline 4 & $\begin{array}{l}\text { Proppant } \\
\text { with Liquid } \\
\text { Resin } \\
\text { System }\end{array}$ & $\begin{array}{l}\text { All previously discussed methods were based on proppants which } \\
\text { are covered by resin coating in the place of origin, i.e. a plant. } \\
\text { Another method can replace the former one by pumping a special fluid } \\
\text { composition during the main treatment at the final pumping stages. } \\
\text { This is called a Liquid Resin System, introduced by various authors. } \\
\text { The generalized ranges of applicability of the method are given in the } \\
\text { decision matrix (Table 3, row 4). }\end{array}$ & $\begin{array}{l}\text { Krismartopo et al., 2005; } \\
\text { Nguyen et al., 2003; } \\
\text { Sidorov and Sabitov, } \\
\text { 2010; Trela et al., } 2008 \text {. }\end{array}$ \\
\hline 5 & $\begin{array}{l}\text { Proppant } \\
\text { covered by } \\
\text { Surface } \\
\text { Modifica- } \\
\text { tion Agent } \\
\text { (SMA) }\end{array}$ & $\begin{array}{l}\text { The addition of SMAs to the surface of proppants allows for a decrease in } \\
\text { proppant flowback by filming the grains and thus, increasing the friction } \\
\text { coefficient between them. According to laboratory experiments SMA } \\
\text { contributes to many advantageous designs. Field observation reveals that } \\
\text { SMAs are not suitable in high rate wells, but are more reliable in low and } \\
\text { moderate rate wells. The summarized area of potential application of the } \\
\text { method is given in the decision matrix in Table } 3 \text {, row } 5 \text {. }\end{array}$ & $\begin{array}{l}\text { Al-Zakwani et al., 2001; } \\
\text { Browne and Wilson, 2003; } \\
\text { Nguyen et al., 2013; } \\
\text { Parker et al., 1999; Van } \\
\text { Batenburg et al., 1999; } \\
\text { Weaver et al., } 1999 .\end{array}$ \\
\hline 6 & $\begin{array}{l}\text { Proppant } \\
\text { with } \\
\text { Consolida- } \\
\text { tion Aid } \\
\text { (PCA) }\end{array}$ & $\begin{array}{l}\text { In the research of Lu et al., 2018, the results of laboratory experiments give } \\
\text { the characteristics of a special composition named Proppant Consolidation } \\
\text { Aid (PCA). This composition consolidates any type of proppant by gluing } \\
\text { grains to each other. The features of the technology are its independence of } \\
\text { pressures and temperatures because the consolidation effect is based on a } \\
\text { physical interaction rather than chemical interactions between grains and } \\
\text { PCA. The main conditions when the method can be applied are given in } \\
\text { Table 3, row } 6 .\end{array}$ & Lu et al., 2018 \\
\hline 7 & $\begin{array}{l}\text { Cylindrical } \\
\text { proppant }\end{array}$ & $\begin{array}{l}\text { In 2010, this method was applied for the first time and tested } \\
\text { in Arta field, Egypt. Technologically, this proppant could be applied } \\
\text { in almost any situations and conditions, and the only constraint } \\
\text { for the method is its cost and economics, as well as its availability } \\
\text { in a particular region. Letichevskiy et al., } 2015 \text { list the area of cylindrical } \\
\text { proppant applications. Cylindrical proppant is normally made of bauxite, } \\
\text { which means two consequences: first, it has high strength, and second, } \\
\text { it costs more than RCP. Some authors concluded that the method allowed } \\
\text { for the production of more hydrocarbons in comparison with conventional } \\
\text { RCP application as per the results of total production from wells. } \\
\text { The details are in Table 3, row } 7 \text {. }\end{array}$ & $\begin{array}{l}\text { Edelman et al., 2013; } \\
\text { Letichevskiy et al., 2015; } \\
\text { McDaniel et al., 2010; } \\
\text { Valiullin et al., 2015. }\end{array}$ \\
\hline
\end{tabular}


Table 4: Continued

\begin{tabular}{|c|c|c|c|}
\hline \# & Method & Description & References \\
\hline 8 & Microfibers & $\begin{array}{l}\text { One of the widespread methods to overcome the proppant flowback problem } \\
\text { is the application of microfibers. } \\
\text { As per the study of James et al., 1998, there is a variety of microfibers types, } \\
\text { and one distinction in the classification is the capability to withstand acid and } \\
\text { high temperatures. } \\
\text { Edelman et al., } 2013 \text { observed that it is hard to mix proppant, fibers, and } \\
\text { gels during pumping downhole. Another field observation is that fibers } \\
\text { slightly decrease the fracture conductivity due to some inter-grain space } \\
\text { filling. Browne and Wilson, } \mathbf{2 0 0 3} \text { noticed that the effect of fibers to decrease } \\
\text { proppant flowback is not so significant, but putting a well into production is } \\
\text { accompanied by difficulties with fibers equipment blockages. } \\
\text { Ramones et al., } 2014 \text { suggest implementing Fiber Based Proppant Flowback } \\
\text { Control technology. The technology based on the usage of fibers activated } \\
\text { only under certain temperature threshold at about } 80^{\circ} \mathrm{C} \text {. Generally, the fields } \\
\text { of fiber application are given in Table } \mathbf{3} \text {, row } 8 \text {. }\end{array}$ & $\begin{array}{l}\text { Browne and Wilson, 2003; } \\
\text { Card et al., 1995; Cudney } \\
\text { et al., 1997; Edelman et } \\
\text { al., 2013; James et al., } \\
\text { 1998; Krismartopo et al., } \\
\text { 2005; Howard et al., 1995; } \\
\text { Ramones et al., 2014; Zhu } \\
\text { et al., 2014. }\end{array}$ \\
\hline 9 & $\begin{array}{l}\text { Thermoset } \\
\text { Resin Fibres }\end{array}$ & $\begin{array}{l}\text { This type of microfiber technology was developed for high temperature } \\
\text { conditions where conventional glass fibers cannot withstand. In-depth } \\
\text { research and the development of high temperature fibers were done by } \\
\text { James et al., 1998. These fibers are stable above } 300^{\circ} \mathrm{C} \text {, they have stability } \\
\text { in organic solvents and hydrochloric acids, and other harsh environments. } \\
\text { As per the laboratory results by James et al., 1998, experimental field trials } \\
\text { have revealed good well performance without proppant flowback. } \\
\text { The summarized conditions when Thermoset Resin Fibers can be applied are } \\
\text { shown in the decision Table 3, row } 9 .\end{array}$ & James et al., 1998. \\
\hline 10 & $\begin{array}{l}\text { Thermo- } \\
\text { plastic Film } \\
\text { Strips (TFS) }\end{array}$ & $\begin{array}{l}\text { Thermoplastic Film Strips technology was first introduced in the laboratory } \\
\text { and field research of Nguyen et al., 1996. The technology implies the } \\
\text { addition of TFS into proppant when mixing. TFS is a material represented as } \\
\text { strips with a certain length (normally the length of a strip is the length of } \\
\text { several grains), and it can bond proppant by increasing the friction factor } \\
\text { between grains. Summarized conditions of TFS application are provided in } \\
\text { Table 3, row 10. }\end{array}$ & Nguyen et al., 1996. \\
\hline 11 & $\begin{array}{l}\text { Deformable } \\
\text { isometric } \\
\text { particles } \\
\text { (DIP) }\end{array}$ & $\begin{array}{l}\text { Deformable Isometric Particles (DIP) technology has become popular in } \\
\text { dealing with proppant flowback. Successful field case studies in more than } \\
1000 \text { wells are present. The material represents a cellulose core coated by a } \\
\text { resin cover, while the core makes up } 85-94 \% \text { of the total grain volume. } \\
\text { Rodgerson et al., } 2003 \text { discussed the cases when DIP was used in a well } \\
\text { where hydraulic fracturing was performed in a more than } 300 \text { m thick } \\
\text { interval. The majority of conditions when the technique can be applied are } \\
\text { given in the decision matrix (Table 3, row 11). }\end{array}$ & $\begin{array}{l}\text { Rae et al., 2001; } \\
\text { Rodgerson et al., 2003; } \\
\text { Stephenson et al., } 1999 \\
\text { Stephenson et al., } 2003 \text {. }\end{array}$ \\
\hline 12 & $\begin{array}{l}\text { Expandable } \\
\text { proppant }\end{array}$ & $\begin{array}{l}\text { One of the newest laboratory proved technologies is Expandable Proppants. } \\
\text { This technology was not tested at a field scale, but nevertheless, it has a great } \\
\text { potential in dealing with proppant flowback. The material is made of shape } \\
\text { memory polymers (SMP) which start increasing their volumes under a } \\
\text { certain downhole temperature, thus packing the fracture. Based on the } \\
\text { information from Santos et al., 2018 studies, we defined the applicability } \\
\text { criteria for the methods and summarized in the decision Table 3, row 12. }\end{array}$ & Santos et al., 2018. \\
\hline 13 & $\begin{array}{l}\text { Polymer } \\
\text { Surface } \\
\text { Modified } \\
\text { Proppant }\end{array}$ & $\begin{array}{l}\text { In the study of Fu et al., 2016, a new material to deal with proppant } \\
\text { flowback was introduced. The material coats the proppant grain surfaces. The } \\
\text { composition of the material is poly 2-fluorine-4vinilpyridine with the } \\
\text { addition of methanol. The proppant grains' surface modification allows for a } \\
\text { proppant pack to re-aggregate after disaggregation. For the moment, this } \\
\text { method was only laboratory-scale tested without any field trials. The main } \\
\text { conditions when the method can be applied are listed in the decision matrix } \\
\text { in Table 3, row 13. }\end{array}$ & Fu et al., 2016. \\
\hline 14 & $\begin{array}{l}\text { In-situ } \\
\text { Formulated } \\
\text { Proppant }\end{array}$ & $\begin{array}{l}\text { One of the latest inventions is a material that creates a hard proppant from a } \\
\text { liquid at downhole conditions. The technology was introduced by Chang et } \\
\text { al., } \mathbf{2 0 1 5} \text { as an alternative to conventional proppants. The idea of the method } \\
\text { is to formulate hard grains from liquid compositions when the latter enters } \\
\text { the fracture. The grains can withstand high stresses up to } 95 \mathrm{MPa} \text { and no } \\
\text { damage or creation of fines occurs. The big advantage of the technique is that } \\
\text { it is pumped in liquid state, thus no risk with premature screen-out is present. } \\
\text { In Table 3, row } \mathbf{1 4} \text { the main conditions when the method is applicable are } \\
\text { given. }\end{array}$ & Chang et al., 2015. \\
\hline
\end{tabular}




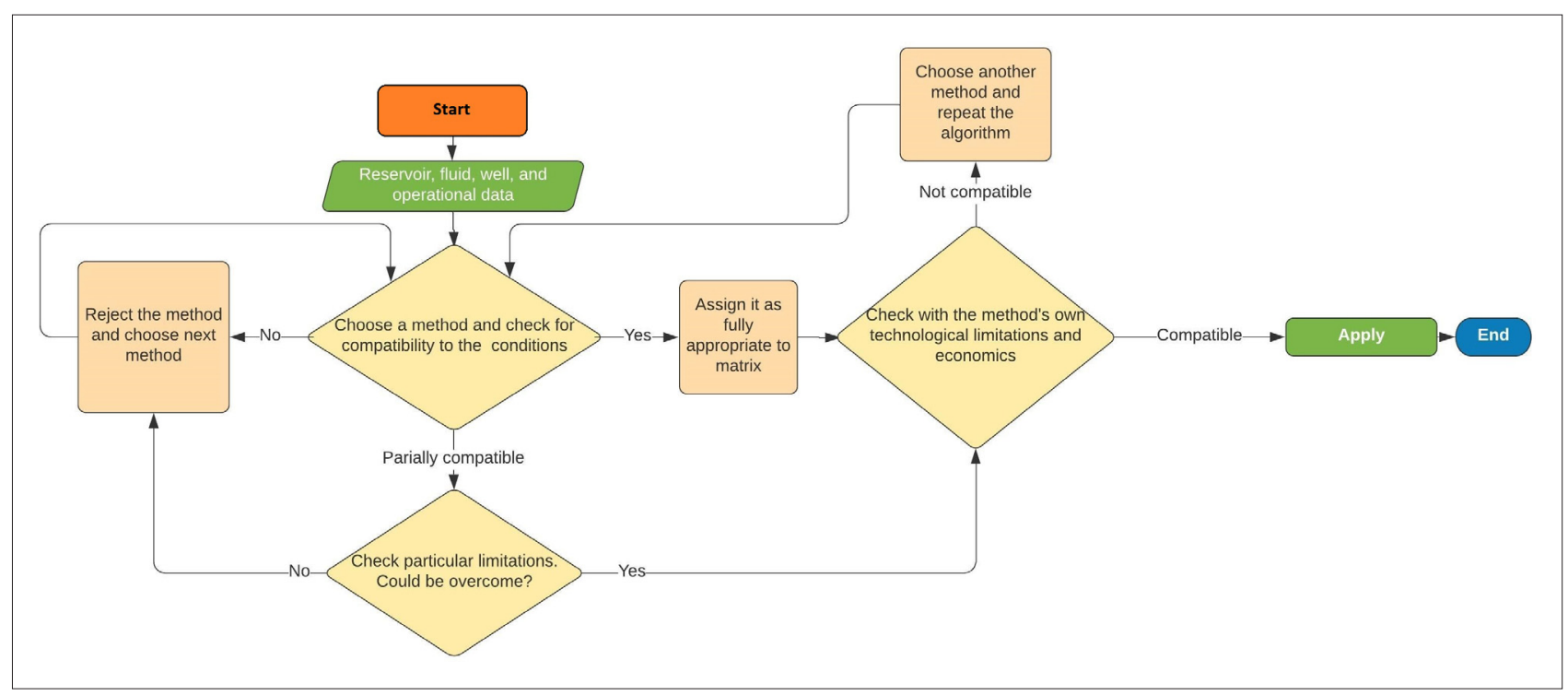

Figure 1: The algorithm for proper proppant flowback mitigation method selection

treatments; as it's known that HF can dissolve quartz and clays, which are the components of many proppants and even small quantities of HF could cause damage to a proppant. So, HF should be excluded from consideration.

- Only technical considerations without economics; due to many uncertainties in economic factors and the complexities in business choices, the economic factor was intentionally left out from the decision matrix.

The next step is to create a special matrix which consists of " 0 " (zeros) meaning a method's inappropriateness and " 1 " (ones) - the appropriateness for the given conditions (see Table 3 ). In addition, the matrix has a "green-yellow-red" colour code. Green with "1" meaning full appropriateness, yellow (with " 1 " or " 0 ") - some cautions and uncertainties, and red with " 0 " - full rejection or withdrawal controversial operation (e.g. refuse $\mathrm{HCl}$ or stream treatments). Further clarifying, "1" and yellow represents a situation when the method could be applied in the condition, but additional considerations are required. " 0 " and yellow could be considered as applicable if special additional conditions are provided. The appropriate conditions are different for various methods, thus a reader should carefully pay attention to that particular case and it is recommended to find more in related supportive references in Table 4.

Through the application of the above rules of the matrix, a user can easily do a quick look analysis and screening using the matrix in order to make a first decision on proppant flowback mitigation method selection corresponding to a particular reservoir and the well conditions. This is based on the fundamental baseline supported by analysis, research, and systematization of more than fifty papers, books, and sources of information which provide the results of laboratory experiments, field observations, analytical, statistical, and other stud- ies. Such categorical quick filtering could have some limitations due to situations where not all parameters are provided with certain quantitative ranges. For example, one cannot exactly say what is the maximum or minimum stress when we set high, intermediate or low stresses. This is for the reader's decision for particular given cases in a location. The same is applied for permeabilities, drawdowns, viscosities, and deviation.

Setting aside particular characteristics of each mitigation method, some general common features for all methods were revealed and are represented in Table 2. All the supporting references for this generalization are given in Table 3 for each method.

Further in the paper, the ground basis of the matrix applicability is provided, being supported by given conditions and certain distinctive characteristics of the methods.

\section{The Decision Matrix Basis}

Based on the comprehensive review of a variety of research on the subject, the following classification descriptive table was generated (see Table 4). The classification table provides the decision matrix shown in Table 3 with the references where one or the other " 0 " and " 1 " with colour codes are supported. Such a method of presenting the matrix allows for the covering of a lot of information from different sources in a convenient and efficient manner.

\section{An Algorithm to Select a Proper Method to Mitigate Proppant Flowback Problem}

Based on the decision matrix provided in Table 3, a new algorithm is introduced that provides a probable 
initial decision about what method to apply on a particular given field (see Figure 1). It is assumed that every case needs its special attention and additional conditions related to a specific method under consideration, but they should be considered as secondary factors and filters. Eventually, the final decision criteria are economics and logistics which are not considered in our study due to high uncertainties in the subjects.

Apart from many advantages of proposing the algorithm and decision matrix, some other limitations are present that also have to be taken into account. For example, some criteria are not set numerically, but set qualitatively in the form of some category, e.g. while screening relative to permeabilities, stresses, viscosities, drawdowns we don't provide exact ranges of applicability in digital form for any of the methods. That's why such qualitative classification contains some uncertainty that an engineer should keep in mind during decision making. Thus, only relative comparisons could be implemented. Nevertheless, even under such limitations, our proposed algorithm and decision matrix could give the initial ranking of the methods relative to a given problem, provide a quick look analysis, which is normally far cheaper than the application of numerical simulations or providing experimental lab or field trials. Moreover, such a quick look analysis could support what method to apply in the laboratory first, and after lab analysis a final decision for field trials could be made.

\section{Conclusions}

In this paper, the decision matrix is proposed to create a quick look selection of an optimum proppant flowback mitigation method. The initial decision schemes could help fracturing and production engineering teams during the proppant hydraulic fracturing design stages, and provide the basis for a good choice.

Through the review and systematization of fourteen up-to-date preventive methods, the following conclusions can be drawn:

1. To facilitate a comprehensive review, the following selection criteria were set:

a. Proppant flowback reason identification,

b. Physical, chemical, and technological properties of proppant materials,

c. Geological and other formation properties,

d. Well parameters,

e. Technological capabilities,

f. Various operational processes.

2. Common reasons for proppant flowback were identified and systematized.

3. Setting aside particular characteristics of each mitigation method, some general common features for all methods were revealed.

4. Based on the criteria, classification, description, and systematization, the decision matrix was tabulated allowing for the initial ranking and decision-making on what proppant flowback mitigation method is the best one to apply under certain field conditions. The decision matrix could help in advance to find a method with some accuracy and assumptions in hydraulic fracturing design stages. In doing so, convenient ways of data and condition representation by zeros ( 0 ) and ones (1) with colour codes supply the matrix.

5. A special algorithm on how to work with the decision matrix is developed. The algorithm is represented in the form of a flowchart facilitating in the decision-making process.

6. The proposed algorithm and decision matrix could provide a quick look initial selection to support numerical simulations or experimental lab or field trials.

\section{References}

Abbott J., Nosova K. E., Burukhin A. A., Barmatov E.B., Usova Z.Y. (2008): Setting The Standard For Resin Coated Proppant Testing. SPE Russian Oil and Gas Technical Conference and Exhibition, Moscow, Russia, 28-30 October. SPE-115547-MS. https://doi.org/10.2118/115547-MS

Almond S. W., Penny G. S., Conway M. W. (1995): Factors Affecting Proppant Flowback with Resin Coated Proppants. SPE European Formation Damage Conference, The Hague, The Netherlands, 15-16 May. SPE-30096-MS. https://doi.org/10.2118/30096-MS.

Al-Zakwani S., Pongratz R., Fidan E., Kaura J.D. (2001): Management Of Proppant And Fines Back Production In High-Rate Gas-Condensate Wells. SPE Middle East Oil Show, Manama, Bahrain, 17-20 March. SPE-68103-MS. https://doi.org/10.2118/68103-MS.

Bomgardner M. M. (2011): Proppant progress. A workhorse for oil and gas extraction sees material advances amid growing demand. Chem. Eng. News, 89 (36), 38-40. https://doi.org/10.1021/cen-v089n036.p038

Browne D. J., Wilson B. A. (2003) Proppant Flowback Control In Deviated Shallow Gas Wells. Journal of Canadian Petroleum Technology, 42 (11), 29-34. https://doi.org/ 10.2118/03-11-02.

Card R. J., Howard P. R., Feraud J-P. (1995): A Novel Technology To Control Proppant Backproduction. SPE Production \& Facilities, 10 (04), 271-276. https://doi.org/ 10.2118/31007-PA.

Chang F. F., Berger P. D., Lee C. H. (2015): In-Situ Formation Of Proppant And Highly Permeable Blocks For Hydraulic Fracturing. SPE Hydraulic Fracturing Technology Conference, The Woodlands, Texas, USA, 3-5 February. SPE173328-MS. https://doi.org/10.2118/173328-MS.

Cudney G. V., El-Moniem H., Mostafa M. R. (1997): High Permeability Fracturing With A Unique Proppant Flowback Prevention Technique. SPE Middle East Oil Show and Conference, Bahrain, 15-18 March. SPE-37733-MS. https://doi.org/10.2118/37733-MS.

Denney D. (2005): Erosion By Sand And Ceramic Proppants During Slurry Injection And Proppant Flowback. Journal of Petroleum Technology, 57 (03), 35-37. https://doi. org/10.2118/0305-0035-JPT. 
Dewprashad B., Abass H. H., Meadows D. L., Weaver J.D., Bennett B.J. (1993): A Method To Select Resin-Coated Proppants. SPE Annual Technical Conference and Exhibition, Houston, Texas, USA, 3-6 October. SPE-26523-MS. https://doi.org/10.2118/26523-MS.

Duenckel R. J., Barree R. D., Drylie S., O’Connell L.G., Abney K.L., Conway M.W., Moore N., Chen F. (2017): Proppants - What 30 Years Of Study Has Taught Us. SPE Annual Technical Conference and Exhibition, San Antonio, Texas, USA, 9-11 October. SPE-187451-MS. https://doi. org/10.2118/187451-MS.

Edelman J., Maghrabia K., Semary M., Mathur A. K., Zaki A.S., Bernechea J.M. (2013): Rod-Shaped Proppant Provides Superior Proppant Flowback Control In The Egyptian Eastern Desert. SPE Unconventional Gas Conference and Exhibition, Muscat, Oman, 28-30 January. SPE164014-MS. https://doi.org/10.2118/164014-MS.

Fu L., Zhang G., Ge J., Liao K., Jiang P., Pei H., Li X. (2016): Surface Modified Proppants Used For Proppant Flowback Control In Hydraulic Fracturing. Colloids and Surfaces A. Physicochemical and Engineering Aspects, 507, 18-25. https://doi.org/10.1016/j.colsurfa.2016.07.039.

Ghosh S., Rai C. S., Sondergeld C. H., Larese R.E. (2014): Experimental Investigation Of Proppant Diagenesis. SPE/ CSUR Unconventional Resources Conference, Calgary, Alberta, Canada, 30 September - 2 October. SPE-171604MS. https://doi.org/10.2118/171604-MS.

Gorshkov N., Abdrazakov D., Nesterova S., Bolyspayev N. (2018): Influence Of Hydrogen Sulfide On Proppants Performance. SPE Annual Caspian Technical Conference and Exhibition, Astana, Kazakhstan, 31 October - 2 November. SPE-192580-MS. https://doi.org/10.2118/192580-MS.

Green J., Dewendt A., Terracina J., Abrams B., Harper A. (2018): First Proppant Designed To Decrease Water Production. SPE Annual Technical Conference and Exhibition, Dallas, Texas, USA, 24-26 September. SPE-191394MS. https://doi.org/10.2118/191394-MS.

Gubanov V.B., Silin M.A., Magadova L.A., Kemkin E. V. (2009): Resin Coated Proppant Craking Strength Investigation. Oilfield business (Neftepromyslovoe delo), 9, 4245. (in Russian)

Haque M. H., Saini R. K., Sayed M. A. (2019): Nano-Composite Resin Coated Proppant For Hydraulic Fracturing. Offshore Technology Conference, Houston, Texas, 6-9 May. OTC-29572-MS. https://doi.org/10.4043/29572-MS.

Howard P. R., King M. T., Morris M., Feraud J-P., Slusher G., Lipari S. (1995): Fiber/Proppant Mixtures Control Proppant Flowback In South Texas. SPE Annual Technical Conference and Exhibition, Dallas, Texas, USA, 22-25 October. SPE-30495-MS. https://doi.org/10.2118/30495-MS.

Istayev A., Jatykov T., Kosset T. (2019): Hydraulic fracturing in a devonian age carbonate reservoir: a case study. SPE Middle East Oil and Gas Show and Conference, Manama, Bahrain, 18-21 March. SPE-194942-MS. https://doi. org/10.2118/194942-MS.

James S. G., Samuelson M. L., Reed G. W., Sullivan S.C. (1998): Proppant Flowback Control In High Temperature Wells. SPE Rocky Mountain Regional/Low-Permeability
Reservoirs Symposium, Denver, Colorado, 5-8 April. SPE-39960-MS. https://doi.org/10.2118/39960-MS.

Krismartopo B. D. K., Notman L., Kritzler T., Kristiano T.A., Nguyen P.D. (2005): A Fracture Treatment Design Optimization Process To Increase Production And Control Proppant Flow-Back For Low-Temperature, Low Pressured Reservoirs. SPE Asia Pacific Oil and Gas Conference and Exhibition, Jakarta, Indonesia, 5-7 April. SPE-93168-MS. https://doi.org/10.2118/93168-MS.

Kurochkin B.M., Polozkov K.A., Gaftunyak P.I., Polozkov A. V., Ivanov G. A. (2015): Use Of Materials With Adhesion Properties At Oil And Gas Fields Of The Urals-Volga Region, Orenburg Region And Application Of Special Technologies Of Well Cementing In Conditions Of The North Region. Construction of oil and gas wells on land and sea (Stroitelstvo neftyanyh i gazovyh skvazhin na sushe i na more), 9, 37-41 (in Russian)

Kushnarenko D. V., Khoklov D. I., Kharisov R. Y., Komissarov A. N., Ivanovskaya D. A. (2016): Proppant Optimization In The Low Temperature Verkhnaya-Chona Field. Scientific and Technical bulletin of Rosneft' (Nauchnotekhnicheskii vestnik NK Rosneft), ROGTEC, 4, 56-59. (in Russian)

Letichevskiy A., Parfenov A., Belyakova L., Konchenko A., Borisenko A., Parkhonyuk S., Olennikova O., Klyubin A. (2015): Proppant Flow Back Control For Fracturing Low Temperature Formations Of Russia Methodology And Case Studies. SPE Russian Petroleum Technology Conference, Moscow, Russia, 26-28 October. SPE-176650-MS. https://doi.org/10.2118/176650-MS.

Lu W., O’Neil B., Zhang K., Wang C., Quintero H. (2016): Enhancing Proppant Flowback Control Through Surface Treatment Of Proppant. International Petroleum Technology Conference, Bangkok, Thailand, 14-16 November. IPTC 18796-MS. https://doi.org/10.2523/IPTC-18796-MS.

Lu W., O’Neil B., Zhang K., Wang C., Quintero H. (2018): Mitigating Proppant Flowback Through Surface Treatment Of Proppant-Laboratory Studies And Field Performance. SPE International Hydraulic Fracturing Technology Conference and Exhibition, Muscat, Oman, 16-18 October. SPE-191438-18IHFT-MS. https://doi.org/10.2118/ 191438-18IHFT-MS.

McDaniel G. A., Abbott J., Mueller F. A., Anwar A.M., Pavlova S., Nevvonen O., Parias T., Alary J. (2010) Changing The Shape Of Fracturing: New Proppant Improves Fracture Conductivity. SPE Annual Technical Conference and Exhibition, Florence, Italy, 19-22 September. SPE135360-MS. https://doi.org/10.2118/135360-MS.

Nguyen P. D., Weaver J. D., Parker M. A., King D.G., Gillstrom R.L., Van Batenburg D.W. (1996): Proppant Flowback Control Additives. SPE Annual Technical Conference and Exhibition, Denver, Colorado, 6-9 October. SPE36689-MS. https://doi.org/10.2118/36689-MS.

Nguyen P. D., Weaver J. D. (2003): Controlling Proppant Flowback In High-Temperature, High-Production Wells. SPE European Formation Damage Conference, The Hague, The Netherlands, 13-14 May. SPE-82215-MS. https://doi.org/10.2118/82215-MS. 
Nguyen P. D., Bonapace J. C., Kruse G. F., Solis L., Daparo D. (2013): Effectively Controlling Proppant Flowback To Maximize Well Production: Lessons Learned From Argentina. SPE European Formation Damage Conference \& Exhibition, Noordwijk, The Netherlands, 5-7 June. SPE165174-MS. https://doi.org/10.2118/165174-MS.

Norman L. R., Terracina J. M., McCabe M. A., Nguyen P. D. (1992): Application Of Curable Resin-Coated Proppants. SPE Production Engineering, 7 (04), 343-349. SPE-20640PA. https://doi.org/10.2118/20640-PA.

Parker M., Weaver J., Van Batenburg D. (1999): Understanding Proppant Flowback. SPE Annual Technical Conference and Exhibition, Houston, Texas, 3-6 October. SPE56726-MS. https://doi.org/10.2118/56726-MS.

Rae P., Briggiler N., Di Lullo G.D., D\&apos;Huteau E. (2001): New technique for proppant flowback and improved fracture conductivities. SPE Latin American and Caribbean Petroleum Engineering Conference, Buenos Aires, Argentina, 25-28 March. SPE-69580-MS. https://doi.org/ 10.2118/69580-MS

Ramones M., Rachid R., Milne A., Pelaez K., Gutierrez L., Madrid O., Ponce G., Ponce O., Cruz S. (2014): Innovative Fiber-Based Proppant Flowback Control Technique Unlocks Reservoir Potential. SPE Latin America and Caribbean Petroleum Engineering Conference, Maracaibo, Venezuela, 21-23 May. SPE- 169399-MS. https://doi.org/ 10.2118/169399-MS

Rodgerson J. L., Friesen B. E., Entzminger D. J., Brown T. Anderson S. (2003): Innovative Proppant Flow-Back Control Yields 100\% Success In Permian Basin. SPE Annual Technical Conference and Exhibition, Denver, Colorado, 5-8 October. SPE-84577-MS. https://doi.org/10.2118/ 84577-MS

Santos L., Taleghani A.R., Li G. (2018): Expandable Proppants To Moderate Production Drop In Hydraulically Fractured Wells. Journal of Natural Gas Science and Engineering, 55, 182-190. https://doi.org/10.1016/j.jngse.2018. 04.026 .

Shagaleev R.K., Korsukov M.V., Gareev A.M., Novoselova D. V. (2014): Perfection Of A Formation Hydraulic Fracturing Technologies Providing Objects Productivity Stabilization In Time. Oilfield Engineering (Neftepromyslovoe Delo), 12, 29-34. (in Russian)

Sidorov I.V., Sabitov, R.R. (2010): The Analysis Of Technologies On Fastening Proppanta In Cracks Of Hydraulic Rupture Of The Layer. Oil and Gas Territory (Territoriya Neftegas), 4, 56-59. (in Russian)

Stephenson C. J., Rickards A. R., Brannon H. D. (1999): Increased Resistance To Proppant Flowback By Adding Deformable Particles To Proppant Packs Tested In The Laboratory. SPE Annual Technical Conference and Exhibition, Houston, Texas, 3-6 October. SPE-56593-MS. https://doi. org/10.2118/56593-MS.
Stephenson C. J., Crabb T. M., Khachatrian M. B. (2003): Reliable Proppant Flowback Control For Low-Stress, LowTemperature Reservoirs. SPE Western Regional/AAPG Pacific Section Joint Meeting, Long Beach, California, 19-24 May. SPE-83469-MS. https://doi.org/10.2118/83469-MS.

Trela J. M., Nguyen P. D., Smith B. R. (2008): Controlling Proppant Flow Back To Maintain Fracture Conductivity And Minimize Workovers: Lessons Learned From 1,500 Fracturing Treatments. SPE International Symposium and Exhibition on Formation Damage Control, Lafayette, Louisiana, USA, 13-15 February. SPE-112461-MS. https:// doi.org/10.2118/112461-MS.

Valiullin A., Makienko V., Overin A., Yudin A., Gromovenko A. (2015): The First Experience Of Rod-Shaped Proppant Implementation In Western Siberia Oil Fields. SPE Russian Petroleum Technology Conference, Moscow, Russia, 26-28 October. SPE-176540-MS. https://doi.org/ 10.2118/176540-MS.

Van Batenburg D., Biezen E., Weaver J. (1999): Towards Proppant Back-Production Prediction. SPE European Formation Damage Conference, The Hague, The Netherlands, 31 May-1 June. SPE-54730-MS. https://doi.org/ 10.2118/54730-MS.

Vincent M. C., Miller H. B., Milton-Tayler D., Kaufman P.B. (2004): Erosion By Proppant: A Comparison Of The Erosivity Of Sand And Ceramic Proppants During Slurry Injection And Flowback Of Proppant. SPE Annual Technical Conference and Exhibition, Houston, Texas, 26-29 September. SPE-90604-MS. https://doi.org/10.2118/90604-MS.

Vreeburg R-J., Roodhart L. P., Davies D. R., Penny G.S. (1994): Proppant Backproduction During Hydraulic Fracturing-A New Failure Mechanism For Resin-Coated Proppants. Journal of Petroleum Technology, 46 (10), 884-889. SPE-27382-PA. https://doi.org/10.2118/27382-PA

Weaver J. D., Baker J. D., Woolverton S., Parker M.A. (1999): Application Of Surface Modification Agent In Wells With High Flow Rates. Latin American and Caribbean Petroleum Engineering Conference, Caracas, Venezuela, 21-23 April. SPE-53923-MS. https://doi.org/10.2118/53923-MS.

Wei G., Babadagli T., Huang H., Hou L., Li H. (2020): A Visual Experimental Study: Resin-Coated Ceramic Proppants Transport Within Rough Vertical Models. Journal of Petroleum Science and Engineering, 191, 107-142. https://doi. org/10.1016/j.petrol.2020.107142.

Zhu K., Guo D., Zeng X., Li S., Liu C. (2014): Proppant Flowback Control In Coal Bed Methane Wells: Experimental Study And Field Application. International Journal of Oil, Gas and Coal Technology, 7 (2), 189 - 202. https://doi. org/10.1504/IJOGCT.2014.059279.

Zoveidavianpoor M., Gharibi. (2015): A. Application Of Polymers For Coating Of Proppant In Hydraulic Fracturing Of Subterraneous Formations: A Comprehensive Review. Journal of Natural Gas Science and Engineering, 24, 197209. https://doi.org/10.1016/j.jngse.2015.03.024. 


\section{SAŽETAK}

\section{Poboljšanja pri projektiranju hidrauličkoga frakturiranja stijena primjenom metoda smanjenja povrata podupirača tijekom proizvodnje ugljikovodika}

Povrat podupirača nakon postupka hidrauličkoga frakturiranja stijena prilično je velik izazov jer uzrokuje oštećenja proizvodne opreme ugrađene u bušotini kao i površinske opreme te dovodi do neželjenih remontnih radova i gubitka proizvodnje uz druge negativne posljedice. Posebne metode kontrole povrata podupirača, uključujući preventivne i korektivne mjere, već se primjenjuju u naftnome inženjerstvu kako bi se svladali problemi s mogućim povratkom podupirača. Međutim, ne postoje jasne smjernice i kriteriji kako i koju metodu odabrati za određene ležišne uvjete, posebno tijekom pojedine faze projektiranja hidrauličkoga frakturiranja. Stoga su autori proveli sveobuhvatan pregled četrnaest preventivnih tehnologija kako bi ih sistematizirali te predložili način donošenja odluke za početni odabir tehnologije. U radu su razmatrane sljedeće metode koje se primjenjuju: smolom obloženi podupirač (RCP), RCP s aktivatorom, RCP s nanočesticama, podupirač sa sustavima tekućih smola (LRS), podupirač sa sredstvima za modifikaciju površine (SMA), podupirač s konsolidacijskim sredstvom (PCA), cilindrični podupirač, mikrovlakna, termootporna smolasta vlakna, termootporne trake, deformabilne izometrijske čestice (DIP), proširivi podupirač, površinski modificirani polimeri te in situ kreirani podupirač. Pregledom tehnologija određena su fizička, kemijska i tehnološka svojstva svake metode radi odabira kriterija za njihov izbor. Na taj način korisnici već na početku mogu izabrati odgovarajuću metodu za smanjenje povrata podupirača u kanal bušotine za određeno ležište i uvjete u bušotini tijekom početne faze projektiranja hidrauličkoga frakturiranja.

\section{Ključne riječi:}

hidrauličko frakturiranje, povrat podupirača, podupirač obložen smolom, nekonvencionalna ležišta, stara polja

\section{Author's contribution}

Temirlan Jatykov (1) (PhD candidate, Senior Lecturer at KBTU) initialized the idea and produced the decision matrix based on comprehensive review. Bimurat Sagindykov (2) (Associated Professor at Satbayev University, Candidate of Physical and Mathematical Sciences) supervised the algorithm structure. Kuralay Bimuratkyzy (3) (MSc in Petroleum Engineering) provided data collection and refining, and collaborated in analysis procedures. 